\title{
3 '\#Unpresidented'
}

\author{
The Making of The First Twitter President
}

Sara Polak

\begin{abstract}
This chapter examines the dynamics of US American Twitter responses to the Ebola epidemic in West Africa of 2013-5. Particularly, it focuses on Donald Trump's role in the 'Ebola scare' - he tweeted more than a hundred times about Ebola late in 2014 and early in 2015 - in order to gauge how Trump found his feet as a social media agitator. The chapter argues that Trump and activists/social media marketeers around him learned from the Birther movement and the Ebola scare how to act as 'superspreaders' of viral content by employing the racialized contagions they were virtually engaging with.
\end{abstract}

Keywords: Ebola, Donald Trump, Twitter, contagion metaphors, Ebola scare, Patient Zero

\section{The retweetable inarticulacy of Trump's language}

On December 17, 2016, just over a month after his general election victory, and briefly before being inaugurated as $45^{\text {th }}$ president of the United States, Donald Trump made a spelling error in a tweet that immediately went viral. In what could be read as a Freudian slip betraying his unconscious, and millions of people's not-so-unconscious desires, he wrote of an 'unpresidented' act (referring to China's capture of a US drone). ${ }^{1}$ Although the tweet was quickly deleted, the hashtag \# unpresidented continued to linger on social

1 https://www.theguardian.com/us-news/shortcuts/2016/dec/19/trump-spelling-error-actjoycean-virtuosity-carelessness. Accessed 1 March 2020.

Polak, Sara, and Daniel Trottier (eds), Violence and Trolling on Social Media. Amsterdam, Amsterdam University Press 2020 DOI: 10.5117/9789462989481_CHO3 
media, and The Guardian adopted it as 'the word of the year'. ${ }^{2}$ It is an apt example of the oft-noted fact that Donald Trump himself is the one who forges the language for his opponents to resist him with. Other examples are the many varieties of Trump's campaign slogan 'Make America Great Again' ('Make America Sane Again', 'Make America Gay Again') and 'grab them by the pussy' from the Hollywood Access tapes ('pussy grabs back'). ${ }^{3}$

Donald Trump's tweets have become a specific, unique and rapidly expanding body of literature. The media, particularly the 'traditional' media, in the US and elsewhere, have had a hard time deciding how to deal with them. There are numerous pro- and anti-Trump responses to controversial Trump tweets on the platform itself and on other social media platforms, but mass media such as television news and newspapers also report and respond to most of his tweets, which are regularly front-page news inside and outside of the United States. Trump himself has often stressed that he uses Twitter to be able to address Americans directly, without the 'interference' of media networks, which he deeply mistrusts and systematically tries to delegitimize. At the same time Trump, also explicitly, often uses Twitter to divert the attention of the mainstream media, away from other politically perhaps more important topics, by tweeting. ${ }^{4}$

Journalists have a hard time measuring their responses to Trump's tweets. They cannot be ignored because they are messages from the President. Although of course these are not laws or executive orders or memos, Trump himself often seems to believe they have that status, and in a sense they have that effect. For instance, on 26 July 2017 Trump sent three tweets in which he 'banned' transgender people from the military. ${ }^{5}$ While the tweeted ban had no legal power - a month later the White House issued a

2 https://www.theguardian.com/us-news/2016/dec/19/unpresidented-trump-word-definition. Accessed 1 March 2020.

3 https://www.theguardian.com/commentisfree/2017/jan/17/resist-donald-trump-vocabularyresistance-rhetoric. Accessed 1 March 2020.

4 E.g. on 1 July 2017 Trump tweeted: 'The FAKE \& FRAUDULENT NEWS MEDIA is working hard to convince Republicans and others I should not use social media - but remember, I won the 2016 election with interviews, speeches and social media. I had to beat \#FakeNews, and did. We will continue to WIN' https://twitter.com/realdonaldtrump/status/881271748280365056. Accessed 1 March 2020.

5 'After consultation with my Generals and military experts, please be advised that the United States Government will not accept or allow Transgender individuals to serve in any capacity in the U.S. Military. Our military must be focused on decisive and overwhelming victory and cannot be burdened with the tremendous medical costs and disruption that transgender in the military would entail. Thank you.' https://twitter.com/realDonaldTrump/status/890193981585444864. Accessed 1 March 2020. 
memo which did - the tweets were the real bombshell that sparked a huge amount of confusion and discussion in the media, to some extent as a result of their unclarity. They could not be ignored, yet coming at a time when Trump clearly felt the heat of the investigation into Russian interference in the elections, many journalists expressed a worry that this was a diverting manoeuvre from a President who is perhaps in the first place a talented show master, highly adept at redirecting the public's attention. ${ }^{6}$

Similarly, although the now-deleted tweet 'Despite the constant negative press cofveve' (31 May 2017) was obviously unintentional, the 'affair' was hilarious news for days in a fashion that was hardly at Trump's expense. Indeed, later the same day he tweeted 'Who can figure out the true meaning of 'covfefe' ??? Enjoy!"7 Clearly, he or his team realized that the hilarity about the typo worked in his favour. Even his most fanatical opponents had a relatively harmless laugh about it, and many adopted the word, to the extent that it became not just a popular hashtag, but a word, denoting a tongue-in-cheek version of 'coffee', 'coverage', 'kerfuffle' or the newly coined word for the concept of 'sending a text or publishing a tweet prematurely and with egregious spelling errors'. ${ }^{8}$ Even more than the 'Unpresidented' tweet, this tweet generated a kind of cult of using, usually in benevolent jest, a vocabulary introduced in Trump tweets, that arguably extended his control over the public discourse. What these cases share, is the way in which they weaponize Trump's disarming inarticulacy to contribute to a discourse that would not be legitimate if it were not so vague. That such Trumpian discourse works disarmingly is not to say that it succeeds in getting opponents' political support, but it does work to acquire their linguistic support. Any joke - even if it is at Trump's expense - that employs this discourse helps to establish his position of seeming sheepishness. This is a purely cultural 'soft' power, that does not begin to address equally relevant related questions, such as what Twitter's responsibility as a company is in policing expressions on the platform, and whether it matters legally if a tweet comes from Trump's personal account (@realdonaldtrump) or from the official White House presidential account (@POTUS).

Although 'unpresidented' and 'covfefe' were presumably not intentionally coined, both have the apparently irresistible attraction of so many of his expressions - irresistible even to those who set out to do just that. This chapter interrogates why so many Trump tweets are so irresistible. What

6 E.g. Kendzior, 'First They Came for Trans Americans, Who Will Be Next?'.

7 https://twitter.com/realDonaldTrump/status/869858333477523458. Accessed 1 March 2020.

8 https://www.urbandictionary.com/define.php?term=covfefe. Accessed 1 March 2020. 
makes Twitter so peculiarly conducive to Donald Trump's messages? How does it make his inarticulacy a peculiar strength? How does it spread them, and how have Trump and his supporters learned to employ the contagious nature of both language and medium?

\section{History of Trump as a Twitter president}

There is a long history of symbioses between presidents and their favourite media. What radio was for Franklin D. Roosevelt and television for John F. Kennedy is what Twitter is for Donald Trump. In virtually none of these cases was the particular president actually the first president to employ that medium. Calvin Coolidge and Herbert Hoover were broadcast over the radio before Franklin Roosevelt developed his famous intimate radio style for the Fireside Chats; Dwight Eisenhower appeared on television well before John Kennedy became famous as the first president to master the medium. ${ }^{9}$ Barack Obama's electoral success in 2008 was largely ascribed to his campaign's astute use of social media - Facebook, mainly - in acquiring large-scale popular support and a record-breaking number of small donations. ${ }^{10}$ Donald Trump, however, was an avid Twitter user years before Barack Obama became a personal Twitter user as president. ('Hello, Twitter! It's Barack. Really! Six years in, they're finally giving me my own account.' 18 May 2015).${ }^{11}$ While Obama has always remained a sparse tweeter, Trump has tweeted using the @realdonaldtrump handle over 37,0oo times between his registration in March 2009 and March 2018. Moreover, Trump has used the medium to conduct large-scale campaigns for - and against - a number of issues, mostly in direct or indirect criticism of President Obama.

The best-known example is perhaps the cluster of conspiracy theories around Barack Obama's American citizenship, promoted intensely by a group which later came to be called the Birther Movement. This group of right-wing activists, in which Trump had a prominent role, claimed or suggested that President Obama was not a 'natural-born' citizen of the United States, and therefore, under Article Two of the Constitution, had no right to serve as US President, in order to delegitimize Obama's presidency. In an interview with Ashleigh Banfield on Good Morning America he both expressed his seriousness about running for president himself, and his concurrence with 
the Birther Movement's doubts about Obama's Americanness. ${ }^{12}$ When, a month later, Obama released his long-form birth certificate in response to the pressure, Trump credited himself for having forced the President's hand, but did not drop the accusation. Early in 2016, with the Republican primary in which he himself was a candidate underway, Trump used the same tactic against Ted Cruz, another candidate for the Republican nomination, for example in a tweet on 12 February 2016: 'If @TedCruz doesn't clean up his act, stop cheating, \& doing negative ads, I have standing to sue him for not being a natural born citizen. ${ }^{13}$ In this case particularly, the formulation 'I have standing to sue him for not being a natural born citizen', suggests that not being born in the United States is in itself a crime, which is then compounded by lying about it, as Trump falsely alleges. There were actual court cases about Obama's country of origin, which the birthers lost, but the real power of these narratives lies in their attractiveness for the media, particularly social media.

More than ever, the 2016 US General Elections seem to have been decided in the realm of online social media. Hillary Clinton's 'ground game' - campaigning in the offline world, through flyers, canvassing, grass roots organizing and other traditional means - which was widely acclaimed and understood as far superior to Donald Trump's, by pollsters and analysts of both political leanings, appears not to have mattered as much as Trump's big campaign rallies, rabid tweets, and the online trolling and alleged cybercrime committed in support of his candidacy. Some of the key characteristics of Twitter as a medium - the brevity, the habitual omission of reference to sources - seem to have been particularly important for the Trump campaign, because they are well-suited to his style of communication and intentions. To a large extent, Trump and his circle of supporters benefit not only from the algorithmic characteristics and implications of the medium, but also from its reputation of being unfiltered, democratic, and to-the-point. I will argue that Trump learned to use the tactics to undercut opponents and take charge of the discourse which he used in the campaign and employs as president through social media during earlier social media storms such as the Birther Movement. I will specifically unpack the discourse and metaphors developed during the US American Ebola Scare on Twitter in which Trump was also a key player. 


\section{The contagiousness of the Ebola scare}

Between September 2014 and April 2015 hundreds of millions of tweets in English have used the word 'Ebola'; most of these are US American. ${ }^{14}$ It is not always possible to determine the geographical origin of a tweet, but if the subsection of 'Ebola'-tweets that does have geographical metadata is representative, the majority of the Anglophone tweets that mention Ebola originate from the US. Many are from non-governmental organizations, news networks, or from the various involved American federal agencies, but a large subsection is from individuals who are seemingly not directly involved. Neither do they have clear links with Ebola-affected people or areas, nor are they engaged in the effort to combat the disease. A large number of these tweets bespeak genuine or pretend outrage at the risks involved in addressing the outbreak, and fear of the virus infecting Americans in the United States. This fear was reflected in mainstream American media around the same time, particularly after the discovery of a Liberian patient (on 30 September 2014), and three more cases in the course of October 2014, and later after the discovery of a medical doctor who had contracted the virus in New York. ${ }^{15}$ While some of the mainstream media reports about the disease threat to Americans was definitely alarmist, ${ }^{16}$ the scare took on its own life on social media, where it 'went viral' in a far more aggressive manner.

This case is revealing for several reasons: first of all because it is rich in racist 'lulz' (social media parlance for jokes) and fascinations that often draw on pre-existing narratives and conceptual metaphors regarding disease and (West) Africa. Whether or not actual fear was involved, objectification of victims who are fascinating because they are scary and abject offers a perfect vehicle for individual users to become cliques and organized collectives. Donald Trump, then still a business tycoon and reality star, but not yet president or candidate - although he did have well-known ambitions to become that - happened to be a very active participant in this process on Twitter. In so doing, I argue, he laid some of the groundwork, both for his later campaign and for under-the-radar groups, who came to his support strongly in the course of his presidential campaign.

14 Established using the Digital Methods Initiative's tool T-CAT, and the database [Africa], searched for 'Ebola' in English-language tweet text, and where available, geolocation.

15 https://www.cdc.gov/vhf/ebola/outbreaks/2014-west-africa/united-states-imported-case. html. Accessed 1 March 2020.

16 Hasian, Representing Ebola, p. 137. 
In a perceptive analysis of anti-Semitic Alt-Right YouTube star Felix Kjellberg, Jacob Clifton discusses the phenomenon of online Alt-Right groups that seem to appear from nowhere:

We're conditioned to distance ourselves from Reddit dorks, anime-avatar trolls, and suddenly Nazi-identifying furries, and so they stay invisible - until they aren't. They become collectives, at which point it feels like they came from nothing. ${ }^{17}$

Clifton argues that these collectives of self-identifying 'dorks', 'trolls' and 'edgelords' tended for a long time to remain invisible to a larger public, because they are most active on platforms like Reddit and 4 Chan. There they developed, often from gamers or comics fans, into Alt-Right activist collectives. They only became visible, also to audiences beyond Twitter, when they started to 'feed' Twitter, which is primarily a circulation platform. On the feeder platforms, out of sight of the rest of society, online communities evolve in which the members radicalize one another in part as a result of a continued wish to shock one another. ${ }^{18}$ While it might seem that many of such extreme messages do not greatly matter, because they hardly reach any audience, this is missing the point. Edgelords do not usually aim to address their messages to everyone, but to a small group of likeminded users, which is why the term 'edgelord' is used with ironic pride. These expressions can easily move from ironic non-pc jokes that are intended to draw in-group laughs to hatred genuine enough to motivate group action against specific objects (be they Jews, non-Whites, women or any other group).

Apart from the fact that they tend to be active on platforms most users of mainstream platforms like Facebook and Twitter rarely use, another reason why edgelords and their evolving group dynamics are invisible, is because most social media users do not want to see them. They are, to most users' tastes and sensibilities simply gross, even as badass jokes. To give one example a joke that went around on Reddit and Twitter in early 2015 went along the lines of 'Mom: what did your last slave die of? Me: Ebola'.19 Such jokes, more recognizable as deliberate provocations than as jokes, are rife on message boards like 4 Chan and 8 Chan and some subreddits

17 https://www.buzzfeednews.com/article/jacobclifton/pewdiepie-isnt-a-monster-hessomeone-you-know\#.nfNVPxKqv\%20(16\%20February\%202017). Accessed 1 March 2020.

18 Nagle, Kill All Normies.

19 E.g. https://twitter.com/Emoly28/status/566oo1752198373376. Accessed 1 March 2020. 
(Reddit threads around a specific theme or group of users). They seem to rely on casual racism, which remains soft or borderline by virtue of being syntactically or practically incomprehensible. However unseen, though, these groups, and their organizing and radicalization tactics have been around for about a decade. While there are many examples (the Birther movement is one, but the most famous is perhaps Gamergate), the 2014 Ebola scare on US American Twitter is a case that has not been scrutinized in depth so far.

\section{Trump as a superspreader of the Ebola scare}

Donald Trump, however, did, during the Ebola crisis, lead a very specific and seemingly deliberate response to Ebola on Twitter, which politicized the Ebola scare. He incessantly attacked the Obama administration for its supposedly 'weak' handling of the crisis, repeating that the only way to stop Ebola from infecting Americans on a large scale was to stop all flights from Africa. He also argued that Americans going to the affected areas to help affected communities, should not be allowed back into the country, and suggested that those who entered the US with the virus, did so with malignant intentions. In doing so, Trump politicized the crisis, roping the presumed risk into his white nationalist agenda, which, like the birther movement, contributed to the long process that propelled him into the Republican nomination, and the presidency. But simultaneously, and perhaps more importantly, his tweets reflected, interacted with, and spurred on a trend among the evolving Alt-Right on Twitter to dress narratives of white supremacy in very basic and familiar narremes and memes.

Throughout October 2014, Trump tweeted just under eighty times about Ebola (using either 'Ebola' or ‘\#Ebola' in tweets), up to eight, though often two or three times a day - a significant section of his average of 11 tweets per day. To give a sense of the kinds of tweets Donald Trump (@realdonaldtrump) posted about Ebola in October 2014, here are some examples. ${ }^{20}$

Here we go! I stated long ago that we should cancel all flights from West Africa. Now we have Ebola in U.S., AND IT WILL ONLY GET WORSE! (@ realdonaldtrump,1 October 2014)

20 The examples are selected to be representative, but the entire collection of 'Ebola'-tweets can be found here: http://www.trumptwitterarchive.com/archive (search for 'Ebola'). 
Ebola is much easier to transmit than the CDC and government representatives are admitting. Spreading all over Africa-and fast. Stop flights (@ realdonaldtrump, 2 October 2014)

The Ebola patient who came into our country knew exactly what he was doing. Came into contact with over 100 people. Here we go-I told you so! (@realdonaldtrump, 3 October 2014)

This Ebola patient Thomas Duncan, who fraudulently entered the U.S. by signing false papers, is causing havoc. If he lives, prosecute! (@realdonaldtrump, 4 October 2014)

Despite the ever increasing Ebola disaster, Obama refuses to stop flights from West Africa. It's almost like he's saying F-you to U.S. public (@ realdonaldtrump, 7 October 2014)

The CDC chief just said Ebola is spreading faster than Aids. Marines are preparing for a pandemic drill. Stop all flights from West Africa! (@ realdonaldtrump, 10 October 2014)

China is ripping wealth out Africa and yet, as usual, refuses to put anything back to help with Ebola. 'Let the stupid Americans do it!' SAD (@ realdonaldtrump, 10 October 2014)

As ISIS and Ebola spread like wildfire, the Obama administration just submitted a paper on how to stop climate change (aka global warming). (@realdonaldtrump, 14 October 2014)

President Obama has a personal responsibility to visit \& embrace all people in the US who contract Ebola! (@realdonaldtrump, 15 October 2014)

If this doctor, who so recklessly flew into New York from West Africa, has Ebola, then Obama should apologize to the American people \& resign! (@realdonaldtrump, 24 October 2014)

The Ebola doctor who just flew to N.Y. from West Africa and went on the subway, bowling and dining is a very SELFISH man-should have known! (@realdonaldtrump, 24 October 2014) 
President Obama has a major meeting on the N.Y.C. Ebola outbreak, with people flying in from all over the country, but decided to play golf! (@ realdonaldtrump, 24 October 2014)

Many of these messages accord perfectly with the tendencies and mechanisms Priscilla Wald analyzes in Contagious: Cultures, Carries, and the Outbreak Narrative (2008). As Wald notes 'Disease emergence dramatizes the dilemma that inspires the most basic human narratives: the necessity and danger of human contact.' She offers a cultural history and analysis of the role of the narratives in which communicable disease is framed, in addressing the outbreak on a medical and political level. She analyzes narrative framings of communicable disease in the context of religion, the rise of nationalism, globalization, and other cultural trends, as well as the interface with race, class, and sexual orientation.

The outbreak narrative - in its scientific, journalistic, and fictional incarnations - follows a formulaic plot that begins with the identification of an emerging infection, includes discussion of the global networks throughout which it travels, and chronicles the epidemiological work that ends with its containment. ${ }^{21}$

Contagious is both a cultural history of outbreak narratives and a strong plea for taking such narratives seriously, not as implicit 'truths' that might be reproduced in addressing epidemics, but as stories that '[affect] which social structures and whose beliefs, poverty, prejudices, and personalities become the focus of analysis, as well as who is included in the "we" who might have been better off had the virus not been identified'. ${ }^{22}$

Donald Trump, however, is interested exactly in 'reproducing the epidemic's terms', or rather, in using the actual epidemic to fire up the social epidemic of fear and objectification of Africans and migrants in general as infectious and contaminating. This outbreak narrative - like most, Wald shows - reinforces national belonging: 'indeed typically in outbreak narratives, the effort to contain the spread of a disease may involve international cooperation, but is cast in distinctly national terms, especially in the United States'. ${ }^{23}$ Thus, many outbreak narratives foster 'medicalized nativism,' a term coined by the historian Alan Kraut 'to describe how the stigmatization 
of immigrant groups is justified by their association with communicable disease; it implies the almost superstitious belief that national borders can afford protection against communicable disease.. ${ }^{24}$ Trump's repeated call for closing the borders and stopping all flights from Africa imply the notion that a virus cannot travel across a 'closed' border, closely matches that idea. Clearly, in Trump's wilfully dramatic rendering, Ebola is 'like wildfire', that can be contained and sealed off from reaching the United States through borders.

It is obvious that Trump in his Ebola tweets espouses a classic outbreak narrative, with all the basic ingredients. For example, he forcefully buys into the 'Patient Zero' myth - the idea, central to most outbreak narratives, that there is an 'original virus carrier' who is perpetrator rather than victim of the disease, and who knowingly and cunningly infects others. ${ }^{25}$

The Ebola patient who came into our country knew exactly what he was doing. Came into contact with over 100 people. Here we go-I told you so!

Trump implies that the man who was discovered to carry Ebola, although he only became ill after he had entered the United States, did so with a predetermined plan, and aim to infect as many as possible. Trump's final half-triumphant, half hand-wringing exclamation at the end suggests the event is part of a detailed scenario - the outbreak narrative - which he already knows in detail. In that sense, the Ebola epidemic and the medial versatility of the outbreak narrative come in handy for him to promote a narrative he was already campaigning to get others to buy into as well.

\section{The inarticulacy of Ebola rhetoric}

However, virus metaphors, and the infectious cultural fascination around the threat of disease epidemics are not the same as an outbreak narrative. Rather, those metaphors and fascinations are circumstances that facilitate the development of a real structured narrative, in which time and characters play a role, evolves. Many of the hints about the Ebola epidemic together with frames and implications of virus metaphors on social media together suggest an underlying outbreak narrative, which however hardly surfaces as an actual narrative. When Trump on 1 October 2014, after the discovery 
of the first Ebola case in the US tweeted 'Here we go! [...] AND IT WILL ONLY GET WORSE!', his remarks were at once vague - what does 'it' refer to? Where are 'we' going? - and well-tuned into pre-existing cultural notions of what a disease pandemic is like. As such Trump does not offer an outbreak narrative but uses one that can be intuited, and at the same time remains very elusive.

As such, 'the' Ebola outbreak narrative as it evolves on Twitter is especially hard to capture. The outbreak narratives Wald analyzes are outlined in non-fiction books, novels, magazine stories and other more or less longform mainstream media stories, which can be taken to represent the most prevalent or most widely understood outbreak narrative, but in a world in which hypes happen largely on social media this is harder to do (for most researchers studying narratives - although prominent tweets others find by Donald trump are a good start - especially if these are the artefacts that endure over time).

The inarticulate terms in which the outbreak narrative he promotes is framed, is helpful in obfuscating its internal inconsistencies and logical and factual flaws. The vague language ('Here we go!') and the uncompleted thoughts and sentences allow for various interpretations. The narrative is hardly a real narrative, but rather a jumble of loosely connected 140-character messages that invoke a range of pre-existing popular narratives and images, which invite the reader to fantasize along using narremes from popular culture (small narrative units, e.g., the notion of the impending apocalypse).

A tweet like 'This Ebola patient Thomas Duncan, who fraudulently entered the U.S. by signing false papers, is causing havoc. If he lives, prosecute!' explicitly names the victim, and then falsely accuses him of fraud and 'causing havoc', as if these two, fraud and causing havoc were equally illegal. The implication is that being ill with Ebola in the United States is in itself illegal. Next to the obvious medicalized nativism here, Trump invokes another classical convention of outbreak narratives: the 'super-spreader': the idea that there are patients (often 'Patient Zero') who infect a disproportionate number of others, but also: 'the archetypal stranger, both embodying the danger of microbial invasion, and transforming it into the possibility for rejuvenation and growth'. ${ }^{26}$

Trump's 'super-spreader' tweets, like the one above, clearly speak to fear of 'the archetypal stranger' as well as more general anxieties about mobility in a shrinking world, but not explicitly to the possibility of rejuvenation or growth. However, these are present, not in Trump's explicit words, but in his 
own positioning as a largely social-media-driven presidential candidate. The notion of a 'global village' in which health must be treated on a global scale is a prominent part of Wald's analysis, however, she does not specifically address how the Web 2.0 and social media have influenced or changed this dynamic. Writing in 2008, Wald addresses historically recent outbreaks such as HIV/AIDS, avian influenza, and SARS, without attending to their social lives and outbreak narratives in social media.

\section{Dynamics of Twitter and other platforms}

So what does the seemingly open, border-free, and transnational nature of social media interaction present that is new in the dynamics of narrating communicable disease?

While on the one hand these tweets presume (and construct) a nation that can function as a healthy bulwark against corrupting and debilitating disease, it simultaneously attacks its president, Barack Obama. Obama's failure to stop flights from West-Africa in Trump's rendering seems to bear a relation to his race. Coming after the long birther movement campaign in which Trump and a well-organized group of Tea Party supporters planted the notion that Obama was not born in the United States, the suggestion that his foreignness causes Obama to play a malignant role adds to a pre-existing tradition of racist insults. When Trump tweets 'It's almost like he's saying F-you to U.S. public' the direct implication is that Obama himself is part of the problem, indeed of the attack on the nation Ebola represents. Similarly, attacking Obama for 'play[ing] golf' plays in to pre-existing stereotypes of black laziness, and the racist notion that it is inappropriate for a black man to play golf.

Such suggestions of Obama's complicity in the outbreak simultaneously contribute to the idea that the bordered nation can function as a bulwark against the invasion of the Ebola virus, and imply that Obama's identity in itself represents a fracture in the texture of that border. If one accepts the fabrication of Obama as an intruder and impostor himself - a notion strengthened by the idea that a black president should always be working and has by definition no business playing golf - then the extension of that implication is that he is the vehicle for the entrance of the virus into the US. Trump may support his accusations with criticism of Obama's policies (or policies he falsely attributes to Obama), but in essence the message is that Obama's identity 'naturally' causes the leak. This can be observed also in the tweets in which Trump connects Obama's allegedly conscious choice 
to make the US porous to its own detriment, to Obama's own body, as in: 'President Obama has a personal responsibility to visit \& embrace all people in the US who contract Ebola!'

While Trump does not explicitly move beyond claiming that Obama's body politic is at fault in allowing Ebola to enter the US, implicitly it is clear that Obama's body natural is at fault. The idea that he be punished on the body natural is appealing in part because Obama's body natural, and his African roots in the birther movement's racist frame of reference have enabled the nation's porousness. There is a long tradition of seeing the president as an embodiment of the United States, that facilitated the superficial conflation of Obama's allegedly alien status with his alleged complicity in bringing Ebola into the country. Neither allegation is correct but they support each other in a narrative that weaponizes the fear of the other, while using vagueness about the precise meaning and implications of the claims to deny racism, in a way that is fairly usual for outbreak narratives.

Twitter, because of its accessibility and instantaneity, tends to suggests it is both democratizing and, literally, im-mediate, direct, both in terms of speed and transparency. As the company itself asserts in advertisements: 'People use Twitter to gush, geek out, and get informed. Use our tools to target every type of tweet'. ${ }^{27}$ Twitter is, in reality used for far more, and more pernicious, ways of doing things with words. Some of the key 'types of tweet' indeed are performative: they harass, silence misinform, or scapegoat, often in a collective and organized fashion.

The birther movement - and particularly Trump's way of employing it - exemplifies how narratives that appear to gain attention on the strength of their entertainment value, gather very concrete political traction. Twitter, with its classification of 'types' of tweets suggests that tweets may be believed to be authentic expressions of thoughts and feelings. This misunderstands what kinds of messages tweets can be employed for, and also, how messages can evolve, work on several levels, and operate in a context that is not always visible, and leads all too easily to the tendency to take tweets too much at face value.

Since the rise of social media platforms such as Facebook, Twitter, YouTube and Instagram, the concept of virality has taken on a new set of meanings. Of course virality - not even necessarily online - has over the last decades come to be understood to pertain to computer 'viruses' (malware, spyware) that spread through infected data carriers, email, scams, unsecured WiFi networks and other 'carriers', but I limit my discussion here to material that 
is deliberately shared on social media platforms. For something to 'go viral' online means that it succeeds in attracting attention, clicks, shares, likes, or whatever specific platforms enable, far beyond its own direct environment.

The metaphor of digital content 'going viral' relies on the tendency of actual viruses to spread to others who are in contact with the already infected. However, unlike with disease (or malware), in the case of a YouTube video that goes viral, this is usually seen as positive. Indeed, viral videos have the potential to generate large sums of advertising revenue. Online virality is thus close to a connotation of contagiousness that has long been around in marketing and sales: the idea that human longing or need to have or be part of something works like a virus. If your neighbour has it, you are likely to acquire it too. One difference with online virality is that anyone, anywhere in the world can spread the object with incredible ease, and at - seemingly - no cost.

Such viral objects - video footage, photos, memes, tweets - often spread more aggressively than any real virus would, whether airborne or otherwise. Indeed, Trump seems to have discovered that he himself was able to act as a kind of superspreader of the medial Ebola scare, in part through the generic dynamics of social media, and in part through the specific properties of his language. While the very discursive notions of super-spreaders and Patient Zeros often work to unduly incriminate individuals, Trump seems to relish his role as metaphorical superspreader of online fears and trends more broadly. His entire candidacy, of course, could be framed in 'superspreader' terms: he positioned as an archetypal 'stranger' or outsider candidate (more than was justified in fact for a long-time political donor, and potential candidate), and he rhetorically posed as a political promise who embodied not just the danger (to the establishment) of invasion, but also the possibility of 'rejuvenation and growth'.

Thus, Trump seems to have realized the potential power of virus metaphors as a kind of metaphorical virus in and of itself, during and through the Ebola epidemic, although of course without the sophisticated discourse in which Wald analyzes it. James Peacock and Tim Lustig have identified what they term the 'Syndrome Syndrome' - in the current-day Western culture one needs some kind of syndrome to retain a right to human imperfection socially and economically. In a similar fashion one can speak of a 'Contagion Contagion' - the virus metaphor itself enjoys a cultural popularity only too easily considered in its own terms. ${ }^{28}$

If the Alt-Right, and Donald Trump, can be credited with one thing, it is to discover and learn to employ the tremendous power of metaphorical virality 
to implicitly or explicitly make an argument, and particularly to ridicule, inspire fear, collectively enjoy, and shame, often using the latter strategies to achieve the former. Theoretically the power of fear as metaphorically contagious was already well known. Wald notes: 'Morrow was one of many cultural observers who worried that the fear generated by the epidemic was more socially disruptive than the virus. ${ }^{29}$ However, something that existed primarily as a worry, and which is among other things central to the response to epidemics of the Centers for Disease Control, this fear can also be employed to disrupt society or mobilize groups for political gain. While the 'Ebola scare' did not actually disrupt life in the US to a great extent, it did influence the lives of people who were somehow involved directly, and in any case the disruptive intention of these tweets (for instance to interrupt flights from African countries to the US) is clear.

\section{From the Ebola scare to the presidential campaign}

Such social disruption in general is indeed what Trump, and a great many of the Alt-Right's online activists are aiming for. In an extensive interview with New Yorker's Andrew Marantz, Mike Cernovich, 'an expert at using social media to drive alt-right ideas into the heart of American political discourse', ${ }^{30}$ explained how he became leader of the 'Trolls for Trump' movement that aggressively campaigned against Hillary Clinton in the 2016 elections. Although it does not mention any literal virus or epidemic, both interviewer and interviewee are clearly acutely aware of the relevance of the virus metaphor:

Rush Limbaugh had just mentioned \#ZombieHillary on his radio show. The hashtag, referring to Clinton's supposed frailty, had trended the previous day on Twitter, after Cernovich encouraged his followers to use it. 'I would like to claim credit for it, but I can't,' Limbaugh had said. 'Somebody on Twitter did it.' Cernovich told me, 'He'll never mention me by name, but he's at least listening to the periphery.'

People have always expressed extreme views online, but for many years there was no easy way for such opinions to spread. The Internet was a vast landscape dotted with isolated viruses. The rise of social networks was like the advent of air travel: a virus can now conquer the world in a day. ${ }^{31}$ 
If there is one striking trend in many American tweets about Ebola, it is their tendency to compare it to a 'zombie virus' - perhaps because of Ebola's gruesome effects on the body. While Trump does not literally use the word zombie in his Ebola tweets, he does dehumanize Ebola sufferers, suggest that they 'feed' on spreading the disease, and refer to the epidemic as if it were an impending Walking Dead-style zombie apocalypse. For Cernovich then to employ ‘\#ZombieHillary’ as a hashtag to jeer at illness, contributes to the narrative frame in which being ill is a reason to be blamed and suspected of wanting to spread disease. In the same movement, Cernovich himself uses online virality to influence the mainstream discourse from the fringe, a possibility, as Marantz notes, that results from the internet's shift towards an environment that encourages the spread of such 'viruses' like air travel does with actual viruses.

Not only do Cernovich and others use online virality to troll others, and push content into the mainstream that without social media never would make it into the public arena. Since becoming president, but also already before that, Donald Trump himself had a role in mainstreaming Alt-Right messages. Or more specifically, there is a large machine producing pro-Trump memes, often in response to Trump's tweets, which he then retweets, so that they reach a mainstream, mass audience. Thus, many messages that are not seen beyond very specific Alt-Right marginal communities on platforms like Reddit, on the one hand respond to Trump and on the other are made visible by him. One example concerns a video clip in which Trump beats to the ground a person whose head is replaced by the CNN logo. Trump retweeted it on 2 July 2017 (' $\#$ FraudnewsCNN \#FNN') ${ }^{32}$, but it was first made and shared by a Reddit user. Although Trump denies taking the video from that platform, this is its source, and the video became world news after he had shared it, as part of a general campaign to discredit and delegitimize media that are critical of him, particularly CNN.

The original maker of the video pastiche who had pasted the CNN logo into the clip quickly removed it from Reddit when he saw the upheaval it caused, but at that point it had already spread far and wide, both geographically and across different platforms and media. There was no going back. Trump has learned to use such materials, which are on the one hand clear in their message, that Trump wins the battle in and with the media, and on the other imprecise and inarticulate. The metaphor is obviously silly and it is unclear what it refers to exactly, but that is also what produces its comical effect. Trump, time and again, manages to create 
a perfect storm out of something that is 'going around'. He already had experience in that before the Ebola epidemic, but cheering on the Ebola scare also taught him how to employ the dynamics of outbreak narratives in his own resounding yet disjointed manner. Simultaneously Trump's functioning in turning news of the Ebola epidemic into a veritable scare far away from the sites of the epidemic shows how Wald's theory could be 'updated' to include the shape and politics of outbreak narratives in a social-media ecosystem.

\section{Works cited}

Anderson, Benedict. Imagined Communities: Reflections on the Origin and Spread of Nationalism. London: Verso, 1983.

Arthur, P. and K. Bode. Advancing Digital Humanities: Research, Methods, Theories. London: Palgrave, 2014.

Baym, Nancy K. Personal Connections in the Digital Age: Digital Media and Society Series. Malden (MA): Polity Press, 2015.

Booth, Wayne C. A Rhetoric of Irony. Chicago: University of Chicago Press, 1974.

Boyd, D.M., and N.B. Ellison. 'Social Network Sites: Definition, History, and Scholarship'.Journal of Computer Mediated Communication, vol. 13, no. 1, 2008, pp. 210-230.

Buhite, Russell D. and David E. Levy. FDR's Fireside Chats. Norman (OK): University of Oklahoma Press, 2010.

Chadwick, Andrew. The Hybrid Media System: Politics and Power. Oxford: Oxford University Press, 2013.

Clifton, Jacob. 'The Downfall of YouTube's Biggest Star Is a Symptom of a Bigger Illness'. Buzzfeed, 16 February 2017.

Cogburn, Derrick, and Fatima Espinoza-Vasquez. 'From Networked Nominee to Networked Nation: Examining the Impact of Web 2.o and Social Media on Political Participation and Civic Engagement in the 2008 Obama Campaign'. Journal of Political Marketing, vol. 10, no. 1-2, 2011, pp. 189-213.

Dijck, José van. The Culture of Connectivity: A Critical History of Social Media. Oxford: Oxford University Press, 2013.

Fuller, Matthew. Media Ecologies: Materialist Energies in Art and Technoculture. Cambridge (MA): MIT Press, 2005.

Goriunova, Olga. 'The Force of Digital Aesthetics: On Memes, Hacking, and Individuation'. The Nordic Journal of Aesthetics, vol. 47, 2014, pp. 54-75.

Hasian Jr, Marouf A. Representing Ebola: Culture, Law, and Public Discourse about the 2013-2015 West African Ebola Outbreak. Lanham: Rowman \& Littlefield, 2016. 
Jane, Emma Alice. "Your a Ugly, Whorish, Slut': Understanding E-Bile'. Feminist Media Studies, vol. 14, no. 4, 2014, pp. 531-545.

—. "Back to the Kitchen, Cunt': Speaking the Unspeakable about Online Misogyny'. Journal of Media and Cultural Studies, vol. 28, no. 4, 2014, pp. 558-570.

Kendzior, Sarah. 'First They Came for Trans Americans, Who Will Be Next?'. The Globe and Mail, 27 July 2017, https://www.theglobeandmail.com/opinion/firstthey-came-for-trans-americans-who-will-be-next/article35817888/. Accessed 1 March 2020.

Lakoff, George and Mark Johnson. Metaphors We Live By. Chicago: The University of Chicago Press, 2003.

Lauro, Sarah Juliet. The Transatlantic Zombie: Slavery, Rebellion, and Living Death. New Brunswick: Rutgers University Press, 2015.

Levine, Lawrence and Cornelia Levine. The People and the President: America's Conversation with FDR. Boston: Beacon Press, 2002.

Losh, Elizabeth. Hashtag - Object Lessons. London: Bloomsbury Academic, 2019.

-. Virtualpolitik: An Electronic History of Government Media-Making in a Time of War, Scandal, Disaster, Miscommunication, and Mistakes. Cambridge (MA): MIT Press, 2009.

Lustig, T.J., and James Peacock (eds). Diseases and Disorders in Contemporary Fiction. The Syndrome Syndrome. New York, London: Routledge, 2013.

Marantz, Andrew. 'Trolls for Trump: Meet Mike Cernovich, the Meme Mastermind of the Alt-Right'. The New Yorker, 31 October 2016.

Nagle, Angela. Kill All Normies: Online Culture Wars from 4 Chan and Tumblr to Trump and the Alt-Right. New York: Zero Books, 2017.

Neiwert, David. Alt-America: The Rise of the Radical Right in the Age of Trump. New York: Verso Books, 2017.

Parikka, Jussi. Digital Contagions: A Media Archaeology of Computer Viruses, 2nd. updated edition. New York: Peter Lang, 2016.

Phillips, Whitney, and Ryan Milner. The Ambivalent Internet: Mischief, Oddity, and Antagonism Online. Malden (MA): Polity Press, 2017.

Poell, T., and J. van Dijck. 'Social Media and Activist Communication', in The Routledge Companion to Alternative and Community Media, edited by C. Atton. London: Routledge, 2015, pp. 527-537.

Schaefer, M.T. Bastard Culture! How User Participation Transforms Cultural Production. Amsterdam: Amsterdam University Press, 2011.

Shifman, Limor. Memes in Digital Culture. Cambridge (MA): MIT Press, 2013.

Shildrick, Margrit. Leaky Bodies and Boundaries: Feminism, Postmodernism and (Bio)Ethics. London: Routledge, 1997.

Sunstein, Cass R. \#Republic:Divided Democracy in the Age of Social Media. Princeton, Oxford: Princeton University Press, 2017. 
Thibodeau, Paul H., and Lera Boroditsky. 'Metaphors We Think With: The Role of

Metaphor in Reasoning'. PLoS ONE, vol. 6, no. 2, 2011.

Trottier, Daniel. Identity Problems in the Facebook Era. New York: Routledge, 2013.

-. Social Media as Surveillance: Rethinking Visibility in a Converging World.

Farnham: Ashgate, 2012.

Tufecki, Zeynep. Twitter and Tear Gas: The Power and Fragility of Networked Protest.

New Haven: Yale University Press, 2017.

Wald, Priscilla. Contagious: Cultures, Carriers, and the Outbreak Narrative. Durham

(NC): Duke University Press, 2008.

\section{About the author}

SARA POLAK (Leiden University Centre for the Arts in Society) is assistant professor in American Studies, focusing on US presidents and their media. She wrote "This is Roosevelt's World" - FDR as a Cultural Icon in American Memory (Johns Hopkins University Press, 2021) and co-edited Embodying Contagion: The Viropolitics of Horror and Desire in Contemporary Discourse (University of Wales Press, 2021). She currently focuses on Trump's Twitter use. Polak teaches American literature, culture and history, and regularly comments on US politics and culture in Dutch media. 